\title{
Вікові особливості морфометричних змін екзокринного апарату підшлункової залози
}

\author{
А. П. Мокра, А. Г. Шульгай, О. І. Пелешок \\ Тернопільський Аержавний медичний університет \\ ім. І. Я. Горбачевського, Україна
}

Ключові слова: піАшлункова залоза, екзокриноцити, вивідні протоки, морфометрія, вікові зміни

Вступ. За останні роки спостерігається чітке зростання поширеності патології підшлункової залози (ПЗ) в осіб молодого віку. Серед етіологічних причинних факторів значне місце належить неправильному харчуванню, способу життя, а також генетичним факторам. ПЗ входить до складу гепатопанкреатодуоденального комплексу і часто при порушенні функції однієї з його складових втягується в патологічний процес $[2,6]$. У патогенезі змін ПЗ велику роль відіграють ішемічні та нервово-рефлекторні впливи. Важливе значення у забезпеченні функціональної здатності ПЗ належить стану іiі паренхіми, зокрема екзо- та ендокриноцитів [7]. Для розроблення запобіжних коригувальних впливів морфофункціональних змін ПЗ при тій чи іншій патології важливим $є$ встановлення особливостей іiі структурної організації у різних вікових групах [8]. Останнє може стати основним прогностичним фактором визначення глибини та ступеня зворотного розвитку морфологічних порушень у період адаптаційних та компенсаторних змін. Об'єктивним методом оцінки морфологічного стану органа є кількісний метод, який дозволяє на основі проведених морфометричних вимірювань зробити обгрунтовані висновки [3-5]. У зв'язку з цим, вивчення характерних морфологічних особливостей екзокринних відділів ПЗ у різних вікових групах $є$ актуальним і має важливе практичне значення.

Метою дослідження було встановити морфометричні параметри складових екзокринних відділів ПЗ різних вікових груп білих щурів.

Матеріали і методи. Дослідження проведені на 24 практично здорових білих щурах-самцях, яких поділили на дві групи: 1-ша - статевозрілі (віком 8 міс. та масою 200-210 г); 2-га — старі (24-місячні). Евтаназію щурів здійснювали кровопусканням в умовах кетамінового наркозу. Вирізали шматочки ПЗ, які фіксували в 10,0\% нейтральному розчині формаліну та після проведення через етилові спирти зростаючих концентрацій поміщали в парафін. Мікротомні зрізи забарвлювали гематоксиліном та еозином, за Ван Гізон, Маллорі.

Окремо забирали ПЗ для виготовлення напівтонких зрізів, які забарвлювали толуїдиновим синім.

Гістологічні мікропрепарати та напівтонкі зрізи досліджували світлооптично та морфометрично. Морфоме- трично визначали діаметр ядер екзокриноцитів, діаметр ацинусів, кількість екзокриноцитів на зрізі ацинуса. Вираховували площу ядер екзокриноцитів, площу перерізу цитоплазми екзокриноцитів, ядерно-цитоплазматичні відношення, площу перерізу ацинусів [1]. Окремо також визначали питому вагу паренхіми та питому вагу строми. Отримані цифрові величини обробляли статистично. Різницю між порівнювальними морфометричними параметрами визначали за критерієм Стьюдента.

Результати досліджень та їх обговорення. Паренхіма ПЗ представлена зовнішньосекреторними клітинами (екзокриноцитами), які формують ацинуси, та внутрішньосекреторними клітинами (ендокриноцитами), які формують острівці. Стромальний компонент ПЗ представлений сполучнотканинним каркасом, утвореним колагеновими волокнами, в якому знаходяться як фібробласти, так і фіброцити. До складових стромальної частини ПЗ належать кровоносні та лімфатичні судини, нерви, вивідні протоки. Питома вага стромального компонента у будові П3 різних вікових груп щурів $є$ різною і в молодих тварин становить $(17,28 \pm 0,34) \%$, а у старих тварин $(21,09 \pm 0,46) \%$. 3 віком у щурів збільшується питома вага сполучнотканинного каркасу, яка має виражену достовірну різницю ( $<<0,001)$. Питома вага паренхіми у молодих щурів становить $(82,31 \pm 1,29) \%$ і з низьким показником значущості $(\mathrm{p}<0,05)$ переважає аналогічні дані у тварин 2-ї групи, які становлять $(78,58 \pm 0,84) \%$. Різниця дорівнює $(3,78 \pm 0,01) \%$.

Ацинуси ПЗ мають округлу форму і сформовані екзокринними ациноцитами конічної форми. Розміри ацинусів у щурів різних вікових груп є різними (табл. 1). У тварин 1-ї групи діаметр ацинусів становить $(34,21 \pm 0,18)$ мкм і на 6,2\% переважає діаметр ацинусів тварин 2-ї групи ( $<<0,001)$. Площа ацинусів, яка включає вставний протоковий відділ разом із екзокриноцитами, у молодих щурів становить $(907,58 \pm 3,61)$ мкм $^{2}$, а у 24-місячних щурів $(807,86 \pm 4,28)$ мкм² $^{2}$ Між величинами даних параметрів існує значуща різниця із високим ступенем достовірності ( $<<0,001)$. Світлооптичними дослідженнями гістологічних та напівтонких зрізів встановлено, що кількість клітин екзокриноцитів, які формують ацинус у молодих тварин, на 4,7\% більше порівняно зі старими тваринами. Цитоплазма даних клітин має зернистий вигляд, що особливо виражено в апікальному полюсі. Ядра екзокриноцитів розташовуються у базальній частині клітин. Діаметр ядер у молодих щурів становить $(4,23 \pm 0,03)$ мкм і на $2,6 \%$ переважає аналогічний параметр у старих щурів $(\mathrm{p}<0,05)$. При цьому площа ядер з високим рівнем значущості ( $<$ 0,001) переважає у молодих щурів над площею ядер у старих. Важливою характеристикою функціонального стану екзокриноцитів та їхньої активності є питома 


\begin{tabular}{|c|c|c|c|c|c|c|c|}
\hline \multirow[b]{2}{*}{ 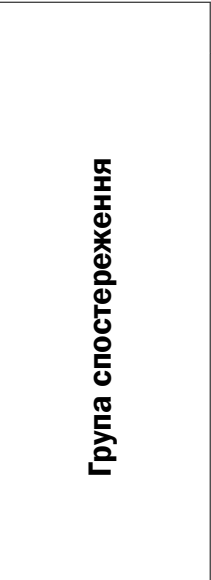 } & \multicolumn{7}{|c|}{ Аосліджуваний параметр } \\
\hline & 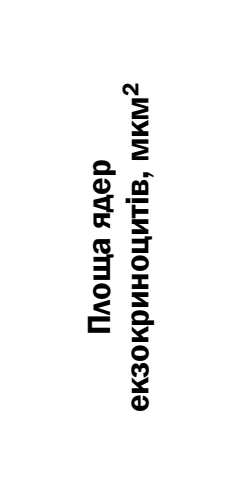 & 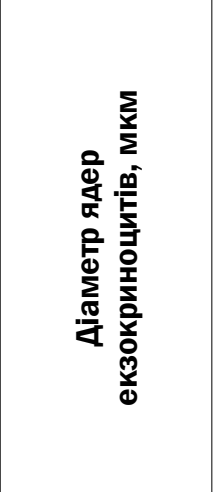 & 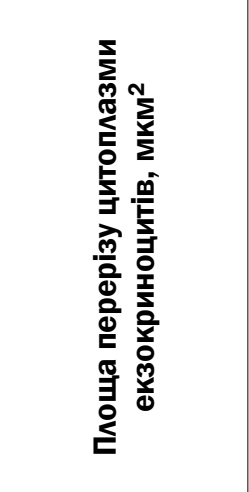 & 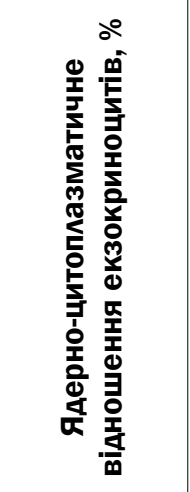 & 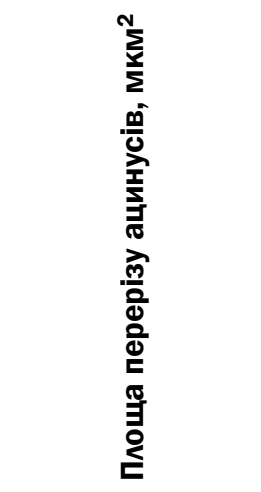 & 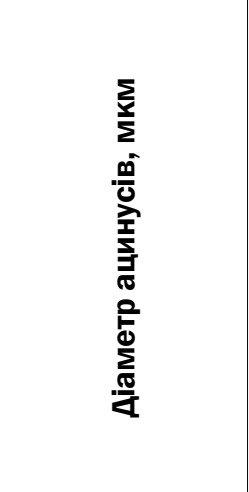 & 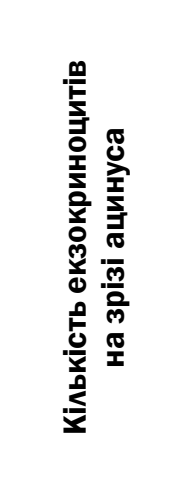 \\
\hline $\begin{array}{l}\text { 1-ша група } \\
\text { (молоді щури) }\end{array}$ & $14,05 \pm 0,03$ & $4,23 \pm 0,03$ & $50,18 \pm 0,32$ & $0,28 \pm 0,02$ & $907,58 \pm 3,61$ & $34,21 \pm 0,18$ & $7,96 \pm 0,42$ \\
\hline $\begin{array}{l}\text { 2-га група } \\
\text { (старі щури) }\end{array}$ & $13,32 \pm 0,04 * *$ & $4,12 \pm 0,02 *$ & $53,83 \pm 0,46 * *$ & $0,25 \pm 0,01$ & $807,86 \pm 4,28 * *$ & $32,08 \pm 0,23 * *$ & $7,58 \pm 0,29$ \\
\hline
\end{tabular}

Примітки: *p < 0,05; **p < 0,001 - у порівнянні величин 1-ї експериментальної групи з 2-ю.

вага цитоплазми та її структурних компонентів. Із проведених морфометричних вимірів та обчислень встановлено, що площа перерізу цитоплазми екзокриноцитів у статевозрілих молодих щурів та у старих тварин є обернено пропорційною до площі їхніх ядер. При цьому площа цитоплазми у старих щурів на $6,8 \%$ переважає аналогічні величини, отримані у молодих щурів $(\mathrm{p}<0,001)$. Функціональна активність кожної клітини визначається структурними взаємозв'язками ядра та цитоплазми. В екзокриноцитів ПЗ вони мають особливе значення, адже пов'язані 3 безпосереднім забезпеченням процесів травлення та подальшого всмоктування простих речовин. При цьому важливим $\epsilon$ також встановлення параметрів співвідношень ядра та цитоплазми у різних вікових групах, що дозволить встановлювати ступінь та можливості їх компенсаторних здатностей. Ядерно-цитоплазматичні відношення можуть змінюватися залежно від гіпер- або гіпофункції клітини та вказувати на ступінь зрілості та диференціації клітини. 3 проведених досліджень видно, що величини параметрів ядерно-цитоплазматичних відношень екзокриноцитів молодих щурів на 10,7\% переважають аналогічні дані у старих щурів, чим засвідчують те, що з віком у даних дослідних тварин знижується функціональна активність ПЗ та їі вплив на процеси травлення.

До складу зовнішньосекреторних відділів ПЗ належить i протокова система, яка забезпечує надходження секрету екзокриноцитів у дигестивну систему. До вивідних проток відносяться вставні протоки, внутрішньочасточкові та міжчасточкові протоки. Геометрія вивідної системи у різних вікових групах даного виду тварин $€$ різною. Вставні протоки представлені одношаровим епітелієм. Діаметр вставних проток у молодих статевозрілих щурів становить $(5,81 \pm$ $0,17)$ мкм, а у старих щурів, які належать до 2-ї групи, $(5,23 \pm 0,10)$ мкм. Співвідношення даних параметрів має статистичну відмінність $(\mathrm{p}<0,05)$. Просвіти внутрішньочасточкових та міжчасточкових проток у старих щурів, навпаки, переважають над спорідненими параметрами, отри- маними у молодих щурів. Діаметр внутрішньочасточкових проток у тварин 1-ї групи становить $(20,38 \pm 0,19)$ мкм, у тварин 2-ї групи - $(22,79 \pm 0,15)$ мкм, а міжчасточкових проток у тварин 1-ї групи - $(43,79 \pm 1,27)$ мкм та $(48,56 \pm$ $0,92)$ мкм у тварин 2-ї групи. Причому, не дивлячись на збільшення калібру та порядку галуження вивідних проток, різниця між параметрами просвіту в досліджуваних вікових групах не збільшувалася та становила 11,82 і 10,89\%.

Таким чином, результати проведених досліджень засвідчують існуючу морфометричну різницю у досліджуваних відділах ПЗ молодих та старих білих експериментальних щурів, які необхідно враховувати при проведенні експериментальних досліджень 3 моделюванням патологічних процесів та станів.

\section{Висновки:}

1. У молодих статевозрілих білих щурів питома вага паренхіми ПЗ $є$ більшою на $(3,78 \pm 0,01) \%$ порівняно зі старими щурами. Площа ацинусів ПЗ та їхні діаметри у тварин з віком зменшуються, а питома вага стромального компонента зростає.

2. Ядерно-цитоплазматичні відношення екзокриноцитів ПЗ молодих статевозрілих тварин переважають аналогічні параметри старих тварин, що свідчить про неоднакову функціональну активність зовнішньосекреторної діяльності.

3. У динаміці вікових змін вивідних проток ПЗ спостерігається звуження вставних відділів проток та розширення внутрішньочасточкових і міжчасточкових проток, що засвідчує різну адаптаційну здатність протокової системи в цілому.

Перспективи подальших досліджень. Детальне вивчення структурних змін зовнішньосекреторних і внутрішньосекреторних складових ПЗ дозволить адекватно судити про іiі функціональну спроможність при розвитку патологічних станів. 


\section{ヘітература:}

1. Автандилов Г. Г. Основы количественной патологической анатомии / Г. Г. Автандилов. - М. : Медицина, 2002. $-240 \mathrm{c}$.

2. Аегтрева И. В. Структурные изменения в поджелуАочной железе при ишемической болезни серАца / И. В. Аепярева // Врачебное Аело. - 2007. - № 9. C. 34-37.

3. Збарский И. В. Организация клеточного яАра / И. В. Збарский. - М. : Медицина, 1998. - 200 с.

4. Саркисов А. С. Структурные основы аАаптации и компенсации нарушенных функций / А. С. Саркисов. - М. : Медицина, 1997. - 230 с.

5. Хесин Я. Е. Размеры ялер и функциональное состояние клеток / Я. Е. Хесин. - М. : МеАицина, 1987. - 424 с. 6. Христич Т. М. Роль сосудистого фактора и нарушения микроциркуляции в этиологии панкреатита / Т. М. Христич, Т. Б. КенАзерская // Сучасна гастроентерологія. 2005. - № 6 (26). - C. 35-40.

7. Koopmann M. C. Total parenteral nutrition attenuates cerulean-induced pancreatitis in rats / M. C. Koopmann, M. D. Baumler, C. J. Boehler // Pancreas. - 2010. Vol. 39, No 3. - P. 377-384.

8. Talley J. Practical gastroenterology and hepatology: small and large intestine and pancreas / J. Talley, S. V. Kane. - Blackwell Publishing, 2010. - P. 525.

УAK 611.37:599.323.4

\section{UA Вікові особливості морфометричних змін екзокринного апарату підшлункової залози}

\section{А. П. Мокра, А. Г. Шульгай, О. І. Пелешок}

Тернопільський Аержавний медичний університет ім. І. Я. Горбачевського, Україна

Ключові слова: підшлункова залоза, екзокриноцити, вивідні протоки, морфометрія, вікові зміни

Морфометричними методами встановлено особливості структурної перебудови складових екзокринного апарату підшлункової залози у білих щурів різних вікових груп. Встановлено, що з віком зменшується питома вага паренхіми, збільшується питома вага стромального компонента. 3 віком зменшуються розміри та площа ацинусів, у екзокриноцитах зменшується площа ядра та величини ядерноцитоплазматичних відношень. У Аинаміці вікових змін вивіАних проток підшлункової залози спостерігають звуження вставних віАділів проток та розширення внутрішньочасточкових і міжчасточкових проток, що свіАчить про різну адаптаційну зАатність протокової системи в цілому.
YAK 611.37:599.323.4

\section{RU Возрастные особенности морфометрических изменений экзокринного аппарата поджелудочной железы}

\author{
А. П. Мокра, А. Г. Шульгай, О. И. Пелешок \\ Тернопольский государственный меАицинский универ- \\ ситет им. И. Я. Горбачевского, Украина
}

Ключевые слова: поджелудочная железа, экзокриноциты, выводные протоки, морфометрия, возрастные изменения

Морфометрическими методами установлены особенности структурной перестройки составляющих экзокринного аппарата поджелудочной железы у белых крыс разных возрастных групп. Установлено, что с возрастом уменьшается удельный вес паренхимы, увеличивается удельный вес стромального компонента. С возрастом уменьшаются размеры и площадь ацинусов, в экзокриноцитах уменьшаются площадь ядра и величины ядерно-цитоплазматических отношений. В Аинамике возрастных изменений Выводных протоков поджелудочной железы наблюдается сужение вставных отделов протоков и расширение внутридольковых и междольковых протоков, что подтверждает разную адаптационную способность системы экскреторного аппарата в целом.

\section{EN Age-dependent peculiarities of pancreatic exocrine apparatus morphometric changes}

\section{A. P. Mokra, A. G. Shul'gai, O. Y. Peleshok \\ Ternopil State Medical University n. a. I. Y. Gorbachevsky, Ukraine}

Key words: pancreas, exocrinocytes, excretory ducts, morphometry, age-dependent changes

The peculiarities of pancreas exocrine components structural change in white rats of different age groups were determined by means of morphometric methods. It was found out that parenchyma density decreases and stromal component specific gravity increases with age. The size and area of acini, the area of nucleus surface and the nucleoplasmic ratio in exocrine cells decrease with age. Due to age-dependent changes of pancreatic excretory ducts, the ductile constriction, interlobular and intralobular ducts' dilations are observed. It proves different adaptive capacity of the ductal system in general. 